\title{
TUTELA ANTECIPADA ANTECEDENTE, PRODUÇÃO ANTECIPADA DE PROVAS E PANDEMIA: UM DIÁLOGO NECESSÁRIO
}

\author{
Francislaine de Almeida Coimbra Strasser, Silas Silva Santos \\ Universidade do Oeste Paulista - UNOESTE, Curso de Direito, Presidente Prudente, SP. E-mail: silas@unoeste.br
}

\section{RESUMO}

O texto aborda os institutos processuais da produção antecipada de provas e da tutela antecipada antecedente, tal como previstos no Código de Processo Civil, no contexto crítico da pandemia de Covid-19. A partir de exemplificação prática em cotejo com a análise teórica, ressalta-se que a estabilização da tutela antecipada abriga de modo adequado e conveniente situações emergenciais e transitórias. Da mesma forma, a produção antecipada de provas revela-se importante instrumento destinado à reconstrução de fatos relativos aos impactos da pandemia nas relações jurídicas, permitindo-se que os interessados solucionem os litígios por métodos autocompositivos ou que, mediante o prévio conhecimento dos fatos, avaliem melhor suas chances de êxito em futura demanda, evitando-se a judicialização conforme o caso. Para alcançar os objetivos desejados, aplicam-se os métodos indutivo e dedutivo, sem prejuízo de, às vezes, adotar-se discurso dialético. A pesquisa é do tipo aplicada, qualitativa, jurídico-exploratória e bibliográfica. Palavras-chaves: Tutela Provisória. Estabilização. Produção Antecipada de Provas. Pandemia. Covid-19.

\section{PRIOR ANTICIPATED SENTENCE, EARLY PRODUCTION OF EVIDENCE AND PANDEMIC: A NECESSARY DIALOGUE}

\begin{abstract}
The text deals about the procedural institutes for the anticipated production of evidence and for the previous anticipated sentence, as foreseen in the Code of Civil Procedure, in the critical context of the Covid-19 pandemic. Based on practical examples in comparison with the theoretical analysis, it is emphasized that the stabilization of early guardianship adequately and conveniently shelters emergency and transitory situations. Likewise, the advance production of evidence proves to be an important instrument for the reconstruction of facts related to the impacts of the pandemic on legal relations, allowing interested parties to resolve disputes by self-composing methods or, through prior knowledge of the facts, better evaluate your chances of success in future demand, avoiding judicialization as appropriate. To achieve the desired goals, the inductive and deductive methods are applied, without prejudice to, at times, adopting dialectical discourse. The research is applied, qualitative, legal-exploratory and bibliographic.
\end{abstract}

Keywords: Provisional Decision. Stabilization. Anticipated Production of Evidence. Pandemic. Covid-19.

\section{INTRODUÇÃO}

Com base em recomendações da Organização Mundial de Saúde, o Brasil decretou estado de calamidade em razão da emergência de saúde pública de importância internacional relacionada à Covid-19, com efeitos até 31 de dezembro de 2020. É o que estabelece o Decreto
Legislativo no 6, de 20 de março de 2020. (BRASIL, 2020).

Antes mesmo desse reconhecimento de calamidade pública, a Lei Federal no 13.979, de 6 de fevereiro de 2020, já havia estabelecido as medidas a serem adotadas para enfrentamento da emergência de saúde pública de importância 
internacional decorrente do coronavírus responsável pelo surto de 2019. (BRASIL, 2020)

Dentre as medidas autorizadas pelo Parlamento está aquela que se designou de quarentena, consistente na restrição de atividades. Para o que interessa neste ensaio, avulta a importância das medidas sanitárias que impuseram o fechamento dos estabelecimentos que não desenvolvessem atividades essenciais, circunstância que notoriamente foi - e tem sido capaz de gerar enormes perdas para a econômica nacional.

Seja como for, releva notar que a situação emergencial reconhecida pela Lei $13.979 / 2020$ traz consigo o predicado da transitoriedade, pois se consentiu que ato do Ministério da Saúde disporá sobre a duração desse estado emergencial em tema de saúde pública, desde que tal prazo não supere aquele declarado pela Organização Mundial de Saúde. (BRASIL, 2020).

Diante do cenário de parcial paralisação das atividades econômicas, as relações trabalhistas também foram impactadas, tanto que o Governo Federal se apressou em baixar as Medidas Provisórias no 927, 936, 944 e 946, todas elas voltadas à tentativa de minimizar os efeitos negativos da pandemia nas relações entre empregado e empregador. (BRASIL, 2020)

No âmbito das relações privadas, a Lei no 14.010, de 10 de junho de 2020, instituiu normas de caráter transitório e emergencial para a regulação de relações jurídicas de direito privado em virtude da pandemia do coronavírus (Covid19). De um modo geral, essa regulamentação transitória incidirá até 30 de outubro de 2020. (BRASIL, 2020).

No campo das relações empresariais, tramita no Congresso Nacional o Projeto de Lei no 1397/2020, de autoria do Deputado Hugo Legal. Nos termos da proposição, a lei que se pretende editar institui medidas de caráter emergencial destinadas a prevenir a crise econômicofinanceira do agente econômico, seja ele pessoa natural ou jurídica que exerça ou tenha por objeto o exercício de atividade econômica em nome próprio, independentemente de inscrição ou da natureza empresária de sua atividade; altera o regime jurídico da Recuperação Extrajudicial, instituído pela Lei 11.101, de 9 de fevereiro de 2005; e suspende, em caráter transitório, determinados dispositivos da mesma Lei no 11.101, de 2005, atinentes à Recuperação Judicial, Extrajudicial e Falência, que somente terão vigência enquanto estiver vigente o Decreto Legislativo no 6, de 20 de março de 2020, ou durante o período de eventual prorrogação do estado de calamidade pública. (BRASIL, 2020).

Esse extrato de legislação transitória tem a finalidade de demonstrar que o momento atual vem marcado pela efemeridade, como é típico das situações emergenciais. No instante em que este trabalho é escrito já se passaram mais de 120 dias de restrições que afetam grande parte dos agentes econômicos do Estado de São Paulo. Nem por isso a situação deixa de ser transitória, pois a esperança é a de que num futuro próximo sejam construídos caminhos científicos para a cura ou para a prevenção eficaz da Covid-19 (vacina), inaugurando-se a retomada, ainda que paulatina, de uma normalidade econômica e jurídica.

Para ilustrar essa realidade efêmera, pode-se trabalhar com a noção de onerosidade excessiva capaz de pôr em desequilíbrio as relações entre locador e locatário de estabelecimentos comerciais situados em shopping centers, uma vez que o Poder Público impôs, em alguns períodos, a completa paralisação das atividades desse segmento. Isso também aconteceu com o chamado comércio de rua, com variados efeitos nas relações locatícias não residenciais.

$\mathrm{O}$ atraso ou a impossibilidade de entrega de determinados produtos adquiridos também constitui exemplo de desconforto jurídico gerado pelas ordens sanitárias destinadas a evitar a propagação do coronavírus. Basta imaginar que uma empresa de confecções tenha sido contratada para, em determinado prazo, fornecer uniformes para uma grande rede de postos de combustíveis; em contrapartida, o adquirente emite alguns títulos (duplicatas, por exemplo) que circulam regularmente pelas redes de fomento (factoring); porém, vencido o prazo para entrega dos produtos, esta não se efetua, em razão da paralisação abrupta das atividades da indústria de confecções, cuja atividade não é essencial, muito embora seja essencial a atividade dos postos de combustíveis. Para piorar, imagine-se que os títulos estejam vencidos e tenham sido levados a protesto pelo terceiro cessionário em razão da falta de pagamento.

Não menos preocupante é a situação de um pai ou de uma mãe que pretenda exercer o direito de visitas em relação a um filho que esteja no grupo de risco de contágio do coronavírus. 
Que se dirá de um idoso acometido de Covid-19, titular de plano de saúde que prevê um acompanhante em caso de internação, quando o isolamento é imposto no hospital?

Figure-se, por fim, o exemplo de uma sociedade empresária atuante no ramo da construção civil e que esteja em recuperação judicial; sobrevém a determinação estatal de paralisação das atividades, para se conter o risco de propagação da Covid-19 entre os obreiros.

Note-se que esses exemplos são facilmente reconduzidos às noções de urgência e de transitoriedade, o que enseja a adoção de técnicas processuais capazes de responder eficazmente às necessidades do momento.

Com efeito, numa perspectiva processual, a urgência advém da necessidade de uma resposta célere aos reclamos das partes, ao passo que a transitoriedade deflui da constatação de que, não muito tempo depois, as relações tendem a se estabilizar num estado fisiológico.

Ocorre que, segundo dados do Conselho Nacional de Justiça, a justiça estadual demora em média 2 anos e 4 meses para encerrar a fase de cognição de um processo judicial. (CNJ, 2020)

Em nada surpreende dizer que a demora natural do processo, por si só, já constitui um severo custo para as partes e também para a sociedade, pois enquanto se aguarda uma solução vai se perpetuando a intranquilidade social. Se o processo é método de pacificação social, a demora por essa pacificação já constitui um mal a ser combatido.

O custo financeiro de um processo também não pode ser desprezado, ainda mais diante dos incrementos realizados pelo Código de Processo Civil de 2015 relativamente aos honorários advocatícios da fase recursal. E O cenário mostra-se não muito animador quando se pensa no período pós-pandêmico, pois a retomada da economia dependerá muito do que houver sobrado dos agentes econômicos durante o período pandêmico. Arrisca-se dizer que o consumo, por exemplo, não será aquele que se espera, já que grande parte do universo de consumidores estará em situação de dificuldade financeira.

Se a pandemia e seu consequente distanciamento social já são capazes de gerar efeitos maléficos na saúde emocional da população, imaginem-se as consequências da permanência de discussões jurídicas para além do período pandêmico! 0 desgaste emocional decorrente da litispendência também não é algo que se despreze.

Nessa ordem de ideias e de preocupações, reafirma-se que o acesso à justiça, notadamente em tempos de pandemia, deve ser, tanto quanto possível, adequado, eficiente e tempestivo.

A pergunta que se coloca é se, no estágio atual da processualística brasileira, haveria técnicas processuais capazes de responder adequadamente à situação de urgência e, ao mesmo tempo, de transitoriedade ocasionada pela pandemia de Covid-19. Acredita-se que o regime da tutela antecipada antecedente, com possibilidade de estabilização, configure um bom caminho a ser trilhado na busca de instrumento processual adequado, eficaz e tempestivo, conforme se demonstrará no subtítulo quatro deste artigo.

\section{MÉTODOS}

$O$ artigo foi norteado por pesquisas bibliográficas, leituras e fichamentos, de doutrinas e livros sobre o tema da produção antecipada de provas e da tutela antecipada antecedente. Para alcançar os objetivos desejados, aplicam-se os métodos indutivo e dedutivo, sem prejuízo de, às vezes, discurso dialético. A pesquisa é do tipo aplicada, qualitativa, jurídico-exploratória e bibliográfica.

\section{SITUAÇÕES QUE ENVOLVEM EXAME DE FATOS NO CONTEXTO DA PANDEMIA DE COVID-19}

Os reflexos econômicos gerados pelo distanciamento social, em alguns períodos com imposição até do fechamento do comércio, não são lineares, isto é, não atingem todos os segmentos da economia de modo uniforme.

De fato, no ramo da venda de livros, por exemplo, já se apresentava comum o acréscimo de vendas por meio de plataformas digitais, sendo escassa a existência de livrarias físicas. Logo, é possível entrever que o fechamento de lojas físicas, em razão da necessidade de contenção da propagação da Covid-19, não traria um impacto tão negativo na esfera dos negócios desse tipo de atividade.

Semelhantemente, os produtores e revendedores de máscaras talvez nunca experimentaram tamanha demanda por seus produtos, circunstância que certamente reverbera, positivamente, no nível de faturamento e na solidez financeira desse tipo de empresa. 0 mesmo se pode dizer em relação aos 
produtores de insumos para funcionamento de UTI, tais como os relacionados à venda de ventiladores mecânicos.

Muito diferentemente disso se apresenta a situação pertinente a outros segmentos, tais como o da construção civil, o das festas infantis ou de casamento, o de casa de shows e o de lojas em shopping centers. Note-se que os obreiros da construção civil estariam impedidos de levar adiante as obras em andamento, evitando-se a aglomeração; inúmeras festas acabaram sendo canceladas, e outras nem chegaram a ser agendadas; vários shows também tiveram de ser cancelados; os shopping centers foram fechados, inviabilizando-se a abertura das lojas neles sediadas.

Ora, são inegáveis as diferenças de incidência de reflexos economicamente negativos nas diversas atividades acima exemplificadas, não se podendo perder de vista, além disso, que distinções podem se verificar entre estabelecimentos do mesmo ramo.

Realmente, ao se pensar no segmento de restaurantes ou de lojas de confecções, há aqueles empresários que simplesmente deixaram de faturar, em razão da paralisação das atividades presenciais. Porém, alguns empreendedores, de uma hora para outra, simplesmente reinventaram-se e passaram a disseminar serviços de entrega em domicílio e de vendas on-line, o que, de certa forma, permitiu a manutenção de um fluxo mínimo de caixa apto a manter a empresa.

Esse quadro de exemplos serve para desnudar que a pandemia de Covid-19 não pode servir de fundamento para que todas as relações contratuais sejam revistas em razão de uma possível onerosidade excessiva. A pandemia também não confere escudo absoluto para que $o$ inadimplemento de obrigações seja relevado em razão de caso fortuito ou de força maior. Ademais, nem todas as obrigações tiveram o adimplemento frustrado por força da quarentena determinada pelo Poder Público.

Disso decorre que a análise sobre a incidência de institutos como a frustração do objeto contratual, a onerosidade excessiva e o caso fortuito ou força maior passa, necessariamente, pela verificação concreta de fatos atrelados à realidade circundante de cada relação jurídica.

Para ficar no exemplo da onerosidade excessiva, tenha-se presente que o art. 478, do Código Civil, estabelece que nos contratos de execução continuada ou diferida, se a prestação de uma das partes se tornar excessivamente onerosa, com extrema vantagem para a outra, em virtude de acontecimentos extraordinários e imprevisíveis, poderá o devedor pedir a resolução do contrato.

Sobreleva notar que a circunstância de uma prestação se tornar excessivamente onerosa configura uma situação de fato. O mesmo se pode dizer relativamente ao surgimento de extrema vantagem e à ocorrência de acontecimentos extraordinários. Nessa perspectiva, o Enunciado 175, do Conselho da Justiça Federal, orienta que "[a] menção à imprevisibilidade e à extraordinariedade, insertas no art. 478 do Código Civil, deve ser interpretada não somente em relação ao fato que gere o desequilíbrio, mas também em relação às consequências que ele produz" (JUSTIÇA FEDERAL, 2017). Ou seja, tanto o desequilíbrio superveniente quanto os seus efeitos numa determinada relação jurídica configuram situações de fato que merecem ser investigadas mediante incursões probatórias.

Com efeito, para se aquilatar a presença do fenômeno da onerosidade excessiva, "[é] preciso ver a pessoa e o evento, porém, não abstratamente, mas situadamente, em relação ao tempo e ao espaço, ao seu ambiente ou contexto". (MARTINS-COSTA, 2003, p. 205)

$\mathrm{Se}$ as observações até aqui lançadas estiverem corretas, parece oportuno indagar a respeito do papel que a produção antecipada de provas possa exercer diante de um tal cenário, discussão que ocupará o subtítulo cinco deste texto.

\section{UTILIDADE DA TUTELA ANTECIPADA ANTECEDENTE E SEU REGIME JURÍDICO}

Não é de hoje que se discute a legítima resposta jurisdicional de acesso à justiça, visto que constitui um dos deveres do Estado Democrático de Direito assegurar ao cidadão a concretização dos valores e dos direitos fundamentais consagrados constitucionalmente.

No entanto, uma das maiores mazelas da efetividade da tutela jurisdicional é o tempo. Isso porque a sociedade disciplinar de Foucault, feita de hospitais, asilos, presídios, quartéis e fábricas, não é mais a sociedade de hoje. Em seu lugar, entrou uma sociedade de academias fitness, shopping centers, prédios de escritórios, bancos, aeroportos, laboratórios de genética, ou seja, a sociedade disciplinar passou a ser de 
desempenho, imersa numa lógica capitalista de produção (HAN, 2017, p. 69), a qual, transcendendo para a tutela jurisdicional, deve responder com a tutela adequada às necessidades do direito material.

[...] o tempo-inimigo, que corrói direitos e contra o qual o juiz deve travar uma guerra sem tréguas, mas que até agora não aprendemos como combater. $E$ quantos outros males nos cercam. [...]. A realidade sobre os quais todos estes dispositivos operam é o tempo como fator de corrosão dos direitos, a qual se associa o empenho em oferecer meios de combate à força corrosiva do tempo-inimigo. (DINAMARCO, 2007, p. 12 e 66).

Não obstante, deve ser sopesado que eficiência processual não pode ser sinônimo de pressa, de maneira que toda essa revolução tecnológica não pode transpor para o direito mecanismos frágeis de soluções ágeis para os conflitos, já que qualquer processo tem escopos jurídicos, sociais e políticos, devendo estes ser alcançados por meio da prestação jurisdicional adequada.

É por isso que Mauro Cappelletti (2002, p. 12-13) enfatiza que "o acesso à justiça pode, portanto, ser encarado como o requisito fundamental - o mais básico dos direitos humanos - de um sistema jurídico moderno e igualitário, que pretenda garantir, e não apenas proclamar os direitos de todos".

Noutros termos, deve haver uma relação equilibrada entre a eficiência e a atuação do Estado em prover a segurança jurídica; ainda mais na sociedade contemporânea, em que a tendência de judicialização apresenta-se cada vez maior. De fato, conforme dados do Conselho Nacional de Justiça (CNJ, 2020) o Poder Judiciário finalizou o ano de 2018 com 78,7 milhões de processos em tramitação, aguardando alguma solução definitiva. Desses, 14,1 milhões, ou seja, $17,9 \%$, estavam suspensos, sobrestados ou em arquivo provisório, aguardando alguma situação jurídica futura. Dessa forma, desconsiderados tais processos, estavam em andamento, no fim do ano de 2018, 64,6 milhões ações judiciais.

Para conciliar a eficiência com a celeridade, sem implicar riscos à qualidade da decisão ou vulneração de outras garantias constitucionais, como a ampla defesa e o contraditório, o Código de Processo Civil de 2015 regulamentou as tutelas provisórias como técnicas engendradas para mitigar os efeitos do tempo e das condutas procrastinatórias que afetam a eficiência do Poder Judiciário.

O CPC/2015 (BRASIL, 2015) disciplinou as tutelas provisórias como gênero, cujas espécies são tutelas de urgência (subdividas em antecipadas e cautelares) e tutelas de evidência, isso mediante a utilização de um critério que leva em conta o fundamento para concessão de tais medidas. Para concessão de tutela provisória de urgência, exige-se, a um só tempo, a probabilidade do direito e o perigo de dano ou o risco ao resultado útil do processo (art. 300, caput, do (PC). Já para concessão de tutela de evidência, prescinde-se do elemento urgência, bastando que o direito invocado seja de altíssima probabilidade ou que o réu apresente defesa destituída de maior seriedade (art. 311, do CPC).

No que toca à diferença entre tutela antecipada e cautelar, Milton de Paulo Carvalho Filho (2018, p. 354) leciona que: "enquanto a tutela conservativa tem em vista a cautelaridade, que consiste em assegurar a viabilidade da realização de um direito, a tutela antecipada tem como enfoque a satisfatividade, que efetivamente realiza ou satisfaz o direito".

Assim, a tutela antecipada satisfaz faticamente o direito e, ao fazê-lo, garante que o resultado futuro do processo seja útil à parte vencedora (satisfaz para garantir); já a tutela cautelar garante para satisfazer, ou seja, garante o resultado final do processo preparando e permitindo a futura satisfação do direito. (NEVES, 2019, p. 501).

Conforme já antecipado, o art. 300 do CPC impõe requisitos cumulativos para que se concedam as medidas provisórias de urgência: o autor deve demonstrar a razoável probabilidade de que o direito invocado é capaz de lhe garantir vitória no plano do mérito e o perigo de dano ou risco ao resultado útil do processo.

Nesse sentido, o Enunciado no 143 do Fórum Permanente de Processualistas Civis (FPPC) dispõe: "A redação do artigo 300, caput, superou a distinção entre os requisitos da concessão para a tutela cautelar e para a tutela 
satisfativa de urgência, erigindo a probabilidade e o perigo na demora a requisitos comuns para a prestação de ambas as tutelas de forma antecipada" (NEVES, 2019, p. 505).

A probabilidade do direito invocado "é mais que mera possibilidade e menos que certeza para decidir em caráter definitivo" (CARVALHO FILHO, 2018, p. 354). Dessa forma, a probabilidade deve ser lógica, que é aquela que surge da "confrontação das provas com os elementos disponíveis nos autos, sendo provável a hipótese que encontra maior grau de confirmação e menos grau de refutação nesses elementos" (WAMBIER et al., 2015a, p. 782).

Essa probabilidade deve estar em sintonia com o fim buscado pela medida provisória. Se antecipada, de caráter satisfativo, será analisada a partir do pedido final, com prognóstico favorável em prol do requerente. Se cautelar, o deferimento ocorrerá para assegurar a utilidade do resultado do processo, como se dá com a cautelar de arresto, por exemplo.

De outra parte, a urgência verifica-se quando a demora possa comprometer a realização imediata ou futura do direito. Nesse sentido, José Miguel Garcia Medina (2016, p. 496) afirma que "a tutela de urgência é concedida para se evitar danos decorrentes da demora processual, porque se está diante de uma situação de risco, a impor a concessão de medida de emergência para evitar a ocorrência de dano iminente".

Além desses requisitos positivos, o legislador acrescentou um requisito negativo no art. 300, § 3ㅇ, do CPC/2015 (BRASIL, 2015), consistente na chamada reversibilidade dos efeitos da decisão concessiva da tutela provisória. Carvalho Filho (2018) explica que reversibilidade consiste na possibilidade de reverter os efeitos da decisão, para que as coisas voltem ao status quo ante.

Segundo entendimento do Superior Tribunal de Justiça (STJ), o dispositivo mencionado deixa claro que "a irreversibilidade não diz respeito ao provimento que antecipa a tutela, mas aos efeitos práticos gerados por ele" ${ }^{1}$ Logo, deve ser analisada a situação fática anterior à concessão da tutela antecipada e aquela a ser criada, caso a tutela seja concedida. Se houver possibilidade de reversão, admitir-se-á a concessão da tutela provisória.

\footnotetext{
${ }^{1}$ STJ, 3ạ Turma, REsp 737. 047/SC, Rel. Min. Nancy Andrighi, j. 16.02.2006.
}

Não obstante a letra do CPC, Neves (2019, p. 518) adverte que, mesmo quando a tutela for faticamente irreversível, o juiz poderá excepcionalmente concedê-la, haja vista que um direito indisponível do autor não pode ser sacrificado pela vedação legal. É o caso, por exemplo, de liberação de medicamentos, intervenção cirúrgica ou imediata internação, pois, conforme o mesmo doutrinador, "o plano de saúde ou hospital sempre poderão cobrar o valor da operação na hipótese de revogação da tutela antecipada" (NEVES, 2019, p. 518).

Ademais, o Enunciado no 40 da I Jornada de Direito Processual Civil do Conselho da Justiça Federal dispõe que: "A irreversibilidade dos efeitos da tutela de urgência não impede a sua concessão, em se tratando de direito provável, cuja lesão seja irreversível". ${ }^{2}$

Ressaltam-se, ainda, os casos de irreversibilidade de mão dupla, em que "caberá ao juiz a ponderação do direito mais provável no momento da análise do pedido da tutela antecipada, aplicando-se o princípio da razoabilidade" (NEVES, 2019, p. 519), balanceando os dois males para escolher o menor, como é o caso da concessão da tutela antecipada para atendimento médico quando o autor demonstra que, caso não seja deferido o atendimento, sofrerá lesão irreparável. ${ }^{3}$ Para tais hipótese, o mencionado autor recomenda que o juiz fixe caução a ser dada pelo autor, salvo se beneficiário da justiça gratuita, conforme $\mathrm{o}$ art. 300 , § 10, do CPC.

É importante mencionar também a disposição do art. 302 do CPC, que trata da responsabilidade civil decorrente dos prejuízos que uma parte causar à outra em virtude da execução da medida de urgência. Segundo a

2 Disponível em: https://www.cjf.jus.br/cjf/noticias/2017/setembro/cej-divulgaenunciados-da-i-jornada-de-direito-processual-civil/. Acesso em: 27 jun. 2020.

${ }^{3}$ Informativo no 420 do STJ: 3o Turma, REsp no 801.600-CE, Rel. Min. Sidnei Beneti, j. 15.12.2009. ANTECIPAÇÃO. TUTELA. DESPESAS MÉDICAS. A Turma reafirmou que, embora exista perigo de irreversibilidade do provimento antecipado, é possível a antecipação da tutela quando a falta do imediato atendimento médico pode causar ao paciente dano também irreparável. No caso, a antecipação da tutela foi concedida para custear tratamento médico urgente em bebê que contraiu infecção hospitalar durante internação em UTI neonatal. O pedido de antecipação de tutela foi deferido em agravo de instrumento no Tribunal a quo, interposto em ação de indenização por danos morais e materiais contra a clínica médica. (...). Precedentes citados: REsp no 417.005-SP, DJ 19.12.2002; REsp no 408.828-MT, DJ 2.5.2005; AgRg no $\mathrm{Ag}$ n은 736.826-RJ, DJ 28.11.2007; AgRg no Ag no 502.173-RJ, DJ 29.8.2005, e REsp no 47.032-SP, DJ 13.8.2001. REsp no 801.600-CE, Rel. Min. Sidnei Beneti, julgado em 15.12.2009. 
doutrina, as disposições dos incisos II e III do art. 302 encerram casos de responsabilidade civil objetiva, e as dos incisos I e IV retratam hipóteses de responsabilidade subjetiva (CARVALHO FILHO, 2018, p. 360).

Isso porque, nos casos dos incisos I e IV, se:

[...] a tutela provisória é necessária e devida, conforme a apreciação sumária do juízo, torná-la, posteriormente indevida e atribuir responsabilidade objetiva pela sua fruição implica ignorar a efetiva existência da decisão que anteriormente

a concedeu. Nesses casos, a responsabilidade civil pela fruição da antecipação de tutela depende da alegação e prova de dolo ou culpa. Só há reponsabilidade objetiva diante da sentença de improcedência quando a tutela provisória é obtida de forma injustificada, isto é, com violação à ordem jurídica. ${ }^{4}$ (WAMBIER et al., 2015b, p. 785).

Após as principais considerações a respeito das tutelas provisórias, aprofundar-se-á no procedimento para a concessão da tutela antecipada em caráter antecedente, sua utilidade e seu regime jurídico.

O CPC (BRASIL, 2015) disciplinou, no seu art. 303, a tutela antecipada antecedente para os casos em que a urgência for contemporânea à propositura da ação. Assim, a urgência tem que ser caracterizada na propositura da demanda; caso contrário, a parte deve se valer da ação de conhecimento "em que formulará desde logo o pedido final definitivo, pleiteando, eventualmente, o adiantamento dos efeitos práticos caso a situação de urgência sobrevenha a propositura da demanda" (CARVALHO FILHO, 2018, p. 361).

\footnotetext{
${ }^{4}$ Carvalho Filho $(2018$, p. 360 ) acrescenta que a responsabilidade do requerente existirá nos casos do art. 302, quando a sentença for desfavorável, pois decorre do princípio da sucumbência; quando deixar de recolher as custas e não fornecer o endereço em que a citação deveria ser realizada; quando ocorrerem as hipóteses do art. 309 do CPC ou quando o juiz acolher a ocorrência de prescrição ou decadência.
}

Medina (2016, p. 512) acrescenta que o procedimento é utilizado no momento em que "a situação de urgência estiver ocorrendo quando do ajuizamento da ação. O que se requer, no caso, é a antecipação dos efeitos da tutela final, cujo pedido respectivo é, num primeiro momento, indicado, e deve posteriormente ser confirmado".

Nos termos do art. 303 do CPC (BRASIL, 2015), a petição inicial deve ser simplificada, sem necessidade de observância dos arts. 319 e 320, ambos da mesma legislação federal, demonstrando-se os requisitos ensejadores da antecipação de tutela (probabilidade do direito e perigo de dano ou risco ao resultado útil do processo), além da exigência prevista no art. 303, $\S 50$, do CPC: dados os limites mais enxutos com que se elabora a petição inicial, o autor deve deixar clara a sua opção pela dedução apenas do pedido de tutela antecipada antecedente, de maneira que, uma vez deferida a tutela antecipada pretendida, abrir-se-á a possibilidade para aditamento da petição inicial, nos termos do $\S 1$ o do aludido artigo (WAMBIER et al., 2015a, p. 508).

No entanto, conforme adverte Carvalho Filho (2018, p. 362), o autor não se eximirá de indicar na sua petição inicial o pedido da tutela final, com a exposição da controvérsia envolvendo o bem da vida, até para assegurar o prognóstico favorável do pedido, sob pena de acarretar ao titular dano material irreparável ou risco de ineficácia ao resultado final do processo.

Agrega-se a esse procedimento a novidade trazida pelo art. 304 do CPC, que é a estabilização da tutela antecipada caso não seja interposto, pelo réu, o respectivo recurso contra a decisão concessiva de tutela antecipada antecedente.

Para os casos em que o processo tramita em primeira instância, referido recurso seria, de forma incontestável, o agravo de instrumento, interponível no prazo de quinze dias, nos termos do art. 1.015, I, do CPC (BRASIL, 2015), porque a lei usou de maneira expressa o vocábulo recurso (CARVALHO FLHO, 2018, p. 363). ${ }^{5}$

\footnotetext{
${ }^{5}$ Carvalho Filho (2018, p. 363) ainda acrescenta que, antes da entrada em vigor do Código de Processo Civil, o projeto de lei no Senado, PLS no 166/2010, previa que o réu poderia impedir a estabilização por meio de qualquer impugnação e que, quando o projeto passou pela Câmara dos Deputados (Projeto de Lei no $8046 / 2010)$, houve modificação do texto, substituindo a palavra impugnação por respectivo recurso, disso extraindo-se que o legislador, de forma consciente, restringiu os instrumentos destinados ao réu a impedir a estabilização da tutela, impondo-Ihe
} 
Convém registrar que o Superior Tribunal de Justiça enfrentou essa questão recentemente e sufragou o entendimento segundo o qual, para que a tutela antecipada não se estabilize, faz-se necessário interpor agravo de instrumento da decisão que a concede, uma vez que outro ato processual praticado pelo réu será insuficiente para evitar a estabilização da decisão e consequentemente a extinção do processo, de sorte que o demandado terá que ajuizar ação autônoma com o fim de reformar a estabilidade decorrente da decisão concessiva da tutela antecipada. ${ }^{6}$

Em que pese essa seja a interpretação dominante, existe outra corrente que admite qualquer irresignação, como reconvenção, contestação, bastando a resistência, o inconformismo do réu (WAMBIER et al., 2015a, p. 512). No mesmo sentido Neves (2019, p. 527), ao defender que "o simples fato de o réu ter se insurgido contra a decisão, mesmo que por meio de recurso formalmente imperfeito, já é o suficiente para não aplicação do artigo 304 do $\mathrm{CPC}^{\prime \prime}$, 7 ainda que não acompanhado de pedido expresso ou de anulação da decisão.

A estabilização prevista no supramencionado art. 304 é explicada por Eduardo Arruda Alvim e outros (2019, p.207) como "a conservação autônoma da tutela provisória, independentemente da discussão do mérito, permitindo às partes a fruição dos efeitos práticos obtidos".

Apesar de o supramencionado artigo prever a estabilização da tutela antecipada somente nos casos em que requerida em caráter antecedente, já se forma doutrina crítica estendendo o regime da estabilização também para a tutela antecipada incidental. Segundo Humberto Theodoro Junior e Érico Andrade (2012, p. 13): "nada justifica o tratamento diverso, pois não há diferença substancial entre a estabilização no curso do procedimento de cognição plena ou naquele prévio ou

ajuizar ação de conhecimento para obter decisão de mérito, suportando, ele próprio, o ônus do tempo do processo, invertido em razão da probabilidade do direito e da urgência.

${ }^{6}$ STJ, 1a Turma, REsp 1797365/RS, Rel. Min. Sérgio Kukina, Rel. para acórdão Min. Regina Helena Costa, j. 3/10/2019.

7 Neves (2019, p. 526) complementa, questionando o motivo que levaria o réu a passivamente admitir a estabilização da tutela antecipada, sabendo que bastaria recorrer ou manifestar seu inconformismo. Para tanto, propõe medidas de execução indireta, que podem ser aplicadas pelo juiz de ofício, como: o juiz isentar o réu de pagamento de custas processuais e até do pagamento de honorários advocatícios, já que o código não excluiu a condenação em honorários, como forma de pressionar o réu a deixar de fazer, isto é, para ocorrer a estabilização da tutela. antecedente; em ambos os casos, a tutela sumaria é deferida com base nos mesmos requisitos e cumpre o mesmo papel e função".

A razão parece estar com Neves (2019, p. 525), segundo o qual, se a concessão for inaudita altera partes, a estabilização deve ocorrer nos termos da intepretação gramatical do art. 304 do CPC (BRASIL, 2015), porque, apesar de já existir o processo principal, há nítida proximidade com a concessão antecedente, o que viabiliza a estabilização da tutela antecipada incidental. Diferentemente, se ocorrer a concessão após a citação do réu, em que já se formou a relação jurídica e após a apresentação da defesa, o processo não pode ser extinto sem resolução do mérito diante de uma suposta estabilização da tutela antecipada, mesmo porque o réu já teria se insurgido contra a pretensão do autor, hipótese em que não se admite a estabilização.

Outra questão que merece destaque, em razão de disceptações doutrinárias, é a possibilidade de estabilização quando a tutela antecipada for concedida parcialmente, ou seja, quando houver acolhimento parcial do pedido da tutela antecipada. Didier Junior; Braga; Oliveira, (2015, p. 608) entendem ser possível a estabilização; já Neves (2019, p. 525) leciona que ocorreria indesejável confusão procedimental por estar parcela do pedido estabilizada e outra parcela não estabilizada, a ser decidida em cognição exauriente.

Parece haver razões suficientes para afirmar que a estabilização parcial condiz com o sistema processual em vigor. Isso porque a disciplina do CPC/2015 (BRASIL, 2015) amplia as hipóteses de desmembramento do julgamento do mérito, como nos casos de julgamento antecipado parcial de mérito (art. 356, do CPC) e de recursos parciais (art. 1.002, do CPC). Assim, nada obsta que parcela do pedido seja abarcada pela estabilização, hipótese em que essa porção do mérito não será objeto do aditamento a que se refere o art. 303, § 1으, inc. I, do CPC, evitandose qualquer tumulto procedimental.

Há, decerto, "o risco de a decisão final ser desfavorável ao autor, e se produzir certa contradição com a decisão antecipatória estabilizada. Mas trata-se de mera contradição lógica (não jurídica) que é assumida como natural pelo sistema todas as vezes em que não há o simultaneus processos". (TALAMINI, 2012, p. 29-30).

Noutra perspectiva, acrescente-se que, se não houver a estabilização da tutela concedida, o 
autor tem o ônus de aditar a petição inicial, em quinze dias ou em outro prazo que o juiz fixar, sob pena de extinção do processo sem resolução do mérito, nos termos do art. 303, §2으, do CPC (BRASIL, 2015), com a perda da eficácia da tutela antecipada deferida ${ }^{8}$.

Rememore-se que não é possível a estabilização da tutela antecipada antecedente no âmbito de ação rescisória, conforme a acertada orientação do Enunciado no 43 da I Jornada de Direito Processual Civil do Conselho da Justiça Federal: "Não ocorre a estabilização da tutela antecipada requerida em caráter antecedente, quando deferida em ação rescisória".

Com a estabilização da tutela e a extinção do processo, as partes ainda podem demandar a outra com o intuito de rever, reformar ou invalidar a tutela antecipada concedida, o que se faz por meio da ação própria prevista no art. 304, $\S 2$ ㅇ, do CPC (BRASIL, 2015). Importante enfatizar que a parte tem dois anos, contados da ciência da decisão que extinguiu o processo, para questionar os efeitos da tutela antecipada estabilizada, sob pena de decadência (WAMBIER et al., 2015a, p. 513).

Sobre o assunto, Luiz Guilherme Marinoni leciona que:

[...] a tutela antecipada, após a extinção do processo, conserva os seus efeitos executivos. Melhor dizendo, após a extinção do processo há estabilização da tutela, ou seja, exatamente a conservação dos seus efeitos executivos e dos seus efeitos materiais exauridos [...] isso significa claramente que à estabilização da tutela não pode ser atribuído

\footnotetext{
${ }^{8}$ Ponto relevante é trazido por Carvalho Filho $(2018$, p. 346) sobre as determinações do art. 303, §1ㅇ, I, e art. 304, caput, do CPC. Isso porque o primeiro dispositivo mencionado impõe ao autor o aditamento da petição inicial no prazo de 15 dias, ou outro maior que o juiz fixar, sob pena de extinção, e o segundo assegura a estabilização da tutela quando não interposto agravo de instrumento no prazo de 15 dias. Assim, não teria utilidade o aditamento da petição inicial se o réu não recorresse da estabilização da tutela e ela se estabilizasse. Sugere, portanto, que o juiz dê prazo maior de 15 dias para que o réu seja citado e intimado da tutela provisória concedida e possa exercer a faculdade ou não de interpor recurso. Decorrido tal prazo, sem a interposição do recurso, a partir de então seria adequado o autor ser dispensado do aditamento, proferindo o juiz sentença de extinção do processo, nos termos do art. 304, caput, do CPC.
}

qualquer efeito preclusivo próprio à coisa julgada. $\mathrm{O}$ direito afirmado provável ou a questão jurídica decidida com base em cognição sumária podem voltar a ser discutidos pelo demandado em qualquer processo. (MARINONI, 2017, p. 244-245).

Nessa ação do art. 304, § 20, do CPC (BRASIL, 2015), em que os polos da relação processual estarão invertidos, parece não haver espaço para inversão do ônus da prova, pois a prova do fato constitutivo continua com o autor da ação antecedente, agora réu na ação exauriente. $\mathrm{E}$ ao réu da ação antecedente, agora autor da ação exauriente, tocará, em sendo o caso, a prova de fato impeditivo, modificativo e extintivo do direito. O legislador se valeu da inversão da inciativa para o debate, que se apoia na realização eventual do contraditório por iniciativa do interessado (WAMBIER et al., 2015b, p. 789).

Apesar de a estabilização da tutela não se confundir com o fenômeno da coisa julgada material, nos termos do art. 304, §6으, do CPC (BRASIL, 2015), questiona-se se o decurso do prazo decadencial de dois anos encerraria a possibilidade de ajuizamento de ação para rediscutir, nos exatos termos da lide originária, a antecipação de tutela.

Parte da doutrina entende que, decorrido o prazo de dois anos sem a propositura da ação referida no art. 304, § 2ㅇ, do CPC (BRASIL, 2015), não caberia qualquer outra demanda, nem mesmo a ação rescisória, pois não haveria coisa julgada material para se desconstituir. (DIDIER JUNIOR; BRAGA, OLIVEIRA, 2015, p. 612).

No mesmo sentido apresenta-se a lição de Neves (2019, p. 533-534), segundo a qual não se permite ajuizar supramencionada ação, pois se aplica, na hipótese, o mesmo raciocínio do cabimento de ação rescisória (art. 975, caput, da referida lei federal de 2015), de forma que o direito de ação deve ser exercido dentro daquele prazo decadencial de dois anos, até porque, se assim não fosse, não faria sentido o prazo previsto expressamente na lei.

Outros entendem que, apesar de não existir coisa julgada material no âmbito da estabilização e de ser inadequado o ajuizamento de ação rescisória, seria possível ajuizar ação autônoma para discutir o direito material, após o 
prazo do aludido artigo 304, § 6ㅇ, do CPC (BRASIL, 2015), (MITIDIERO, 2017, p. 147-148).

A despeito de toda celeuma doutrinária, acredita-se que a estabilidade que surge após 0 esgotamento do prazo do art. 304, §5으, do CPC (BRASIL, 2015), deva ter um significado jurídico, a ponto de se pensar numa escalada ou em graus de estabilização. Dessa forma, a estabilidade surgida após aqueles dois anos de prazo decadencial passa a ser qualificada, inviabilizando-se que, em futura demanda, seja revista, reformada ou invalidada a tutela antecipada impregnada de estabilização.

Essa ordem de ideias não equivale a afirmar que a estabilização tenha o mesmo significado de coisa julgada, uma vez que nesta existe o chamado efeito positivo da coisa julgada, algo que não se verifica naquela.

A partir dessas premissas que caracterizam o regime jurídico da estabilização da tutela antecipada, importa resgatar que os exemplos citados no início refletem considerável urgência e, igualmente, notável transitoriedade, predicados que possibilitam afirmar a inegável utilidade do regime da estabilização para fazer frente aos possíveis debates judiciais em torno daquelas questões.

Com efeito, a obtenção de uma revisão contratual temporária, para fins de redução proporcional dos alugueres pagos por lojistas de shopping centers, por exemplo, pode muito bem - e com proveito - ser alcançada pela técnica da antecipação de tutela requerida em caráter antecedente, com possibilidade de estabilização. É que, a depender da intensidade da revisão operada pelo julgador, a parte contrária pode adotar a estratégia de não recorrer, fazendo com que os efeitos da liminar sejam estabilizados, evitando-se toda uma discussão que se arrastaria por algum tempo, talvez até mesmo para depois de já encerrada a pandemia.

O mesmo se pode dizer da hipótese em que determinada sociedade empresária requeira, em virtude da paralisação momentânea de suas atividades, a sustação ou a suspensão dos efeitos de protestos de títulos de dívidas cujo inadimplemento se tenha verificado muito particularmente também em razão da pandemia. Aqui também seria conveniente trabalhar-se com a técnica da tutela antecipada antecedente, com possibilidade de estabilização, haja vista não se descartar que o réu desta demanda não interponha o recurso.
Na seara do direito de família a mesma situação se verifica, pois, é bem factível que o guardião do filho menor, com receio de propagação da doença, simplesmente interrompa todo e qualquer contato físico da criança com o titular do direito de visitas. Nesse contexto, ganha muito relevo, em vez da propositura de uma demanda exauriente para fins de revisão das cláusulas de visitação, o manejo de pedido de tutela antecipada antecedente para garantir, com alguns critérios de segurança sanitária, o acesso físico à criança, especialmente em épocas de comemorações do Dia das Mães ou do Dia dos Pais.

Dúvidas não pairam, a partir de tudo que se revelou sobre o regime jurídico da estabilização da tutela antecipada antecedente, de que as situações emergenciais e temporárias, que qualificam o momento histórico atual, podem encontrar na referida técnica processual um confortável ambiente para solução adequada, rápida e eficiente de litígios.

Resta saber se essa mesma ordem de ideias encontra guarida no campo da produção antecipada de provas, conforme se verá na sequência.

\section{UTILIDADE DA PRODUÇÃO ANTECIPADA DE PROVAS E SEU REGIME JURÍDICO}

De um modo geral, as provas constituem elemento essencial num litígio, já que o direito nasce dos fatos (ex facto oritur jus); esses fatos, quando controvertidos no processo, devem ser demonstrados para que a parte obtenha o reconhecimento do seu direito. Entende-se, portanto, que a prova "é direito fundamental das partes, que emana do princípio do contraditório (art. 5o, LV, da Constituição) e decorrente do direito que estas possuem de influir no convencimento do juiz" (ARRUDA ALVIM, 2019, p. 830).

Assim, num sentido que se pode dizer clássico, o destinatário da prova seria o juiz, porquanto o objetivo atrelado ao direito à prova consiste em convencer o juiz a respeito de fatos controvertidos. Não por outro motivo, o art. 369, do $C P C / 2015$, estabelece que as partes têm o direito de empregar todos os meios legais, bem como os moralmente legítimos, ainda que não especificados no Código, para provar a verdade dos fatos em que se funda o pedido ou a defesa e influir eficazmente na conviç̧ão do juiz.

Como facilmente se percebe, a prova geralmente está vinculada à demonstração de 
fatos que justificam um pedido ou uma defesa já manifestada nos autos. Implica dizer que a atividade probatória tem por alvo fatos já controvertidos no âmbito de um processo determinado, onde se busca a tutela de um direito afirmado. Daí que, nesse sentido, a prova teria um viés meramente instrumental, porquanto destinada a comprovar o suporte fático de determinada situação de vantagem afirmada pelos contendores.

Porém, essas noções vêm sendo superadas, não porque estejam equivocadas, mas porquanto se pode ampliar o significado de um direito à prova. Primeiro, porque o juiz não pode ser considerado o único destinatário da prova, "uma vez que a atividade e o resultado da prova passam a se dirigir, em grande medida, às partes" (ARRUDA ALVIM, 2019, p. 862). Em segundo lugar, e fundado na premissa anterior, deve-se romper com a ideia de "uma estrita vinculação entre prova e julgamento estatal, admitindo-se, contemporaneamente, a existência de um direito à prova autônomo à existência de uma relação processual" (ARRUDA ALVIM, 2019, p. 862).

Nessa perspectiva, a doutrina enuncia um direito autônomo à prova, o qual descende da própria garantia constitucional do devido processo legal, uma vez que negar esse direito autônomo significaria excluir das partes o direito de analisar seus ônus e suas chances em juízo e, dessa forma, buscar caminhos - não necessariamente judiciais - para solução de suas questões (YARSHELL, 2009, p. 340). O mesmo autor acrescenta que o direito autônomo à prova configura instrumento "apto a contribuir para a tutela dos interesses reconhecidos no plano material, se vista a garantia da ação em uma perspectiva ampla suficiente a abarcar todos os meios colocados pelo Estado para superação dos conflitos". (YARSHELL, 2009, p. 255)

A partir desses novos influxos, o direito à prova afina-se com um controle preventivo, que é inerente à inafastabilidade do controle jurisdicional e à adequada cognição (WAMBIER et al., 2015b, p. 1027). Esse controle preventivo está consagrado nos arts. 381 a 383, do CPC/2015, haja vista que se admite a produção de provas não somente como instrumento adequado para formar o convencimento do juiz, mas também, e principalmente, como meio voltado a auxiliar as partes na avaliação de suas chances de êxito numa demanda futura.

Mediante a consagração da produção antecipada de provas, mesmo fora dos casos de urgência, "o ordenamento reconhece que um conflito pode estabelecer-se em torno da própria prova - e reputa importante resolvê-lo em caráter principal, e não como simples providência incidental no bojo do processo para o qual essa prova possa ser útil" (TALAMINI, 2016, p. 75).

Ao possibilitar a apuração prévia dos fatos por meio da ação autônoma de produção de provas, o instituto de que se cogita poderá levar a alguns resultados: a parte pode não promover a ação para discutir um suposto direito, diante do risco da sucumbência; as partes podem se incentivar a resolver o conflito por métodos autocompositivos; a parte ainda pode mover ação para discutir um suposto direito, mas o fará com mais segurança e responsabilidade.

Assim, a produção antecipada de provas constitui medida que auxilia na redução da litigiosidade, seja por incentivar as partes a transigir, seja por desestimulá-las a promover demandas fadadas ao insucesso (WAMBIER et al., 2015a, p. 660).

Estabelecidas essas premissas teóricas, avança-se na análise do modo como o legislador tratou o assunto.

A hipótese de cabimento prevista no art. 381 , I, do CPC, não constitui novidade alguma, pois que $O \quad C P C / 73$ já previa a produção antecipada de provas nos casos em que se receava perdê-la em razão da passagem do tempo. Tal expediente tem lugar quando haja fundado receio de que venha a tornar-se impossível ou muito difícil a verificação de fatos no momento de sua regular produção, de sorte que seu requisito de admissibilidade consiste na demonstração do perigo da demora. É a chamada produção antecipada para a perpétua lembrança da coisa, conforme Alexandre Miura lura (2018, p. 438).

Diferentemente disso, o inciso II do mesmo artigo admite a produção antecipada de provas mesmo sem o requisito da urgência, já que cabe a medida para viabilizar a tentativa de conciliação ou de outro meio adequado de solução de conflitos. Amplia-se, pois, o campo de admissibilidade da produção antecipada de provas para qualquer caso, bastando a parte alegar que a prova assim produzida ensejará maior facilidade na tentativa de solução extrajudicial do conflito (NEVES, 2019, p. 738).

O inciso III do art. 381, por sua vez, diz respeito à necessidade de produção da prova para preparar o ajuizamento de demanda em que se busque a declaração de direito, sem se perder 
de vista que este mesmo inciso também faz referência à antecipação de prova como forma de se evitar a propositura de demanda. Nesses casos, a antecipação da prova tem o condão de fomentar que a parte adote uma postura mais séria e responsável.

$\mathrm{O}$ art. 381, § 10, do CPC/2015, prevê uma quarta e já conhecida hipótese de cabimento, pertinente ao arrolamento de bens como meio de se aquilatar os bens que compõem uma universalidade; essa catalogação de bens, às vezes até desconhecidos do autor, configura meio útil de preparar a ação principal em que se discute a partilha dessa universalidade, como nas ações de inventário e partilha.

Quanto à competência, o art. 381, § 2ㅇ, do $\mathrm{CPC} / 2015$, define que a produção antecipada de provas será proposta tanto no foro de domicilio do réu quanto no local em que a prova deve ser produzida, ficando a critério do autor. A doutrina critica essa opção do legislador, pois não faria sentido a ação ser ajuizada no foro de domicílio do réu para se realizar uma perícia num bem localizado em outra comarca. Numa situação como esta o processo passaria a tramitar substancialmente por meio de carta precatória, razão pela qual se apregoa que o único foro competente deveria ser o do local de produção de provas (NEVES, 2019, p. 739).

Ainda sobre a competência, há que se levar em devida conta que certas posições de direito material ensejariam uma ampliação dos possíveis foros concorrentes; basta lembrar-se da proteção conferida pelo CDC aos consumidores, de sorte que não seria irrazoável defender que, para se manter um bom nível de tutela processual do consumidor, admitir-se-ia a competência do foro do domicílio deste.

O art. 381, § 3ㅇ, do CPC/2015, estabelece que a produção antecipada de provas não previne a competência do juízo para a ação que venha a ser proposta. Além disso, previu-se que, em localidade em que não haja vara federal, a competência será do juízo estadual, nos termos do $\S 4$ 을 do aludido artigo.

Do ponto de vista procedimental, o art. 382 do CPC/2015 impõe ao autor que demonstre o interesse de agir na petição inicial, o que se faz mediante a apresentação das razões que justificam a necessidade de antecipação da prova e por meio da descrição dos fatos sobre os quais a prova há de recair, sob pena de abusos e distorção do instituto, conforme adverte lura (2018, p. 439).
Dessa forma, adota-se o critério da adequação ou idoneidade de certo meio de prova à demonstração do fato. Implica dizer que o autor deve expor qual o fato que busca provar, a utilidade da prova, ou seja, o vínculo que liga a prova àquele fato e que faz que a apuração seja relevante, bem como o meio de prova de que busca se valer ${ }^{9}$ (WAMBIER et al., 2015a, p. 1033).

\footnotetext{
${ }^{9}$ Nesse sentido, vale referir o acórdão proferido pelo STJ no julgamento do Recurso Especial $\mathrm{n}$ ㅇ 1.803.251-SC, assim ementado:

RECURSO ESPECIAL. AÇÃO AUTÔNOMA DE EXIBIÇÃO DE DOCUMENTOS PELO PROCEDIMENTO COMUM. POSSIBILIDADE. PRETENSÃO QUE SE EXAURE NA APRESENTAÇ̃̃O DOS DOCUMENTOS APONTADOS. INTERESSE E ADEQUAÇÃO PROCESSUAIS. VERIFICAÇÃO. AÇÃO AUTÔNOMA DE EXIBIÇÃO DE DOCUMENTOS PELO PROCEDIMENTO COMUM E PRODUÇÃO DE PROVA ANTECIPADA. COEXISTÊNCIA. RECURSO ESPECIAL PROVIDO.

1. A controvérsia posta no presente recurso especial centra-se em saber se, a partir da vigência do Código de Processo Civil de 2015, é possível o ajuizamento de ação autônoma de exibição de documentos, sob o rito do procedimento comum (arts. 318 e seguintes), ou, como compreenderam as instâncias ordinárias, a referida ação deve se sujeitar, necessariamente, para efeito de adequação e interesse processual, ao disposto em relação ao "procedimento" da "produção antecipada de provas" (arts. 381 e seguintes).
}

2. A partir da vigência do Código de Processo Civil de 2015, que não reproduziu, em seu teor, o Livro III, afeto ao Processo Cautelar, então previsto no diploma processual de 1973, adveio intenso debate no âmbito acadêmico e doutrinário, seguido da prolação de decisões díspares nas instâncias ordinárias, quanto à subsistência da ação autônoma de exibição de documentos, de natureza satisfativa (e eventualmente preparatória), sobretudo diante dos novos institutos processuais que instrumentalizam o direito material à prova, entre eles, no que importa à discussão em análise, a "produção antecipada de provas" (arts. 381 e seguintes) e a "exibição incidental de documentos e coisa" (arts 496 e seguintes).

3. O Código de Processo Civil de 2015 buscou reproduzir, em seus termos, compreensão há muito difundida entre os processualistas de que a prova, na verdade, tem como destinatário imediato não apenas o juiz, mas também, diretamente, as partes envolvidas no litígio. Nesse contexto, reconhecida a existência de um direito material à prova, autônomo em si - que não se confunde com os fatos que ela se destina a demonstrar, tampouco com as consequências jurídicas daí advindas a subsidiar (ou não) outra pretensão -, a lei adjetiva civil estabelece instrumentos processuais para o seu exercício, o qual pode se dar incidentalmente, no bojo de um processo já instaurado entre as partes, ou por meio de uma ação autônoma (ação probatória lato sensu).

4. Para além das situações que revelem urgência e risco à prova, a pretensão posta na ação probatória autônoma pode, eventualmente, se exaurir na produção antecipada de determinada prova (meio de produção de prova) ou na apresentação/exibição de determinado documento ou coisa (meio de prova ou meio de obtenção de prova - caráter híbrido), a permitir que a parte demandante, diante da prova produzida ou do documento ou coisa apresentada, avalie sobre a existência de um direito passível de tutela e, segundo um juízo de conveniência, promova ou não a correlata ação.

4.1 Com vistas ao exercício do direito material à prova, consistente na produção antecipada de determinada prova, o Código de Processo Civil de 2015 estabeleceu a possibilidade de se promover ação probatória autônoma, com as finalidades devidamente especificadas no art. 381.

4.2 Revela-se possível, ainda, que o direito material à prova consista não propriamente na produção antecipada de provas, 
Ainda do ponto de vista procedimental, a lei diz que serão citados para a ação de produção antecipada de provas aqueles que tenham interesse nos fatos e na prova. Exemplificando: uma pessoa sofre um acidente no manejo de uma máquina agrícola; o proprietário desta busca a realização antecipada de perícia na referida máquina; a ação, nesse contexto, pode ser intentada contra a vítima, o fabricante e o segurador, para que a prova seja eficaz para todos. Pode-se figurar também a situação em que alguém pretende apurar, por meio de perícia antecipada, a autoria de um software que cedeu onerosamente a outrem, que o alienou a um terceiro; este deve compor o polo passivo da ação probatória autônoma, vez que a prova técnica recairá sobre bem de sua propriedade. É possível que o terceiro não tenha envolvimento na relação decorrente da cessão de direitos, mas, como sua esfera jurídica será afetada com a perícia a ser realizada, ele deve ser citado como interessado (WAMBIER et al., 2015a, p. 662).

Sob outro aspecto, convém observar a ação autônoma de produção de provas tem natureza dúplice, conforme já esclareceu Flávio Luiz Yarshell (2009, p. 327); implica dizer que a prova terá eficácia em relação a todos os que integrarem a relação processual, não importando o polo que ocupem. Dessa forma, o réu poderá

mas no direito de exigir, em razão de lei ou de contrato, a exibição de documento ou coisa - já existente/já produzida - que se encontre na posse de outrem.

4.2.1 Para essa situação, afigura-se absolutamente viável - e tecnicamente mais adequado - o manejo de ação probatória autônoma de exibição de documento ou coisa, que, na falta de regramento específico, há de observar o procedimento comum, nos termos do art. 318 do novo Código de Processo Civil, aplicando-se, no que couber, pela especificidade, o disposto nos arts. 396 e seguintes, que se reportam à exibição de documentos ou coisa incidentalmente. 4.2.2 Também aqui não se exige o requisito da urgência, tampouco o caráter preparatório a uma ação dita principal, possuindo caráter exclusivamente satisfativo, tal como a jurisprudência e a doutrina nacional há muito reconheciam na postulação de tal ação sob a égide do CPC/1973. A pretensão, como assinalado, exaure-se na apresentação do documento ou coisa, sem nenhuma vinculação, ao menos imediata, com um dito pedido principal, não havendo se falar, por isso, em presunção de veracidade na hipótese de não exibição, preservada, contudo, a possibilidade de adoção de medidas coercitivas pelo juiz.

5. Reconhece-se, assim, que a ação de exibição de documentos subjacente, promovida pelo rito comum, denota, por parte do demandante, a existência de interesse de agir, inclusive sob a vertente adequação e utilidade da via eleita.

6. Registre-se que o cabimento da ação de exibição de documentos não impede o ajuizamento de ação de produção de antecipação de provas.

7. Recurso especial provido.

(REsp no 1803251/SC, Rel. Min. Marco Aurélio Bellizze, Terceira Turma, julgado em 22.10.2019, DJe de 8.11.2019). aproveitar-se da mesma ação para pedir a produção de outros meios de prova sobre os fatos expostos pelo autor (art. 382, § 3으, do $\mathrm{CPC} / 2015$ ).

Wambier et al. (2015a, p. 662) acrescentam que o $\S 4$ 을 do art. 382 do CPC/2015 (BRASIL, 2015), ao dispor que não serão admitidos defesa e recurso, merece uma interpretação sistemática à luz do princípio da ampla defesa, porquanto não se pode negar ao réu o direito de se defender, notadamente por meio da alegação de matérias de ordem pública, como ilegitimidade de parte, falta de interesse de agir por inadequação do meio de prova pretendido. Logo, o que não se pode permitir é que, no bojo da ação probatória, se instaure discussão sobre o direito material.

Ressalte-se o exemplo formulado por lura (2018, p. 440): imagine-se que o autor pleiteie a produção de prova pericial de índole contábil, conforme o art. 381, II, do CPC/2015 (BRASIL, 2015), com o objetivo de apurar o quantum debeatur de uma dívida prescrita. Nesse caso, o réu poderá alegar que não há utilidade na produção de provas; se verificada a prescrição, o juiz poderá indeferir a produção da prova, com base no art. 370 , parágrafo único, do $\mathrm{CPC} / 2015{ }^{10}$

Na perspectiva recursal, a literalidade do disposto no $\S$ 4o do art. 382 da mesma lei processual civil dá mostras de sua inconstitucionalidade, conforme já alertara a doutrina de Flávio Luiz Yarshell:

Também foi infeliz a disposição que pretendeu restringir o cabimento de recurso, limitada que foi à hipótese da decisão que indeferir totalmente a produção antecipada da prova. De forma semelhante ao que foi dito sobre a defesa do réu, aqui a lei pareceu ignorar que o deferimento da antecipação pode violar direitos constitucionalmente assegurados, como sigilo, intimidade e privacidade. Ou seja: a lei parece ter

\footnotetext{
${ }^{10}$ Art. 370 do CPC/2015 (BRASIL, 2015): Caberá ao juiz, de ofício ou a requerimento da parte, determinar as provas necessárias ao julgamento do mérito.

Parágrafo único. O juiz indeferirá, em decisão fundamentada, as diligências inúteis ou meramente protelatórias.
} 
partido da falsa premissa de que o deferimento da prova jamais poderia acarretar prejuízo para o demandado; o que é clamoroso equívoco. Portanto, na premissa de que a decisão que deferir a prova também pode ensejar interesse recursal, a supressão legal - tanto mais porque gera injustificado desequilíbrio entre os litigantes - deve, mais uma vez, ser interpretado à luz da Constituição Federal e dos limites trazidos pelo $\S 2$ 응 do art. 382: só não há interesse recursal para tratar de aspectos relativos à valoração da prova ou ao mérito da decisão (salvo, de novo, se isso levar à inadmissibilidade da prova ou de sua antecipação). Em último caso, se não couber recurso, haverá de caber medida impugnativa autônoma. Além disso, no curso do processo é possível, em tese, que haja atos de caráter decisório - sobre competência, composição da relação processual, de deferimento ou indeferimento de quesitos, de nomeação de perito incapaz ou suspeito, apenas para ilustrar - gerar prejuízo imediato e não apenas potencial. Eles ensejarão recurso de agravo na forma de instrumento, pela simples razão de que, como a sentença nada resolverá sobre o mérito, isso tende a tornar realmente desnecessário eventual recurso de apelação; donde não haver como concentrar a impugnação para o final. Nem seria sustentável - porque irracional - que o autor tivesse a faculdade e ônus de apelar exclusivamente para suscitar as irregularidades cometidas ao longo do processo. (YARSHELL, 2015, p. 1042).

Ademais, o Tribunal de Justiça de São Paulo já admitiu a interposição de recurso contra decisões, proferidas no ambiente da produção antecipada de provas, que causam gravame à parte, em obséquio aos princípios da ampla defesa e do contraditório. ${ }^{11}$

Ressalva-se que a matéria impugnável no âmbito desses recursos haverá de estar atrelada a questões de ordem pública, de cabimento e de produção da prova, não se podendo admitir discussões quanto à valoração da prova.

\footnotetext{
11 "PRODUÇÃO ANTECIPADA DE PROVAS - CABIMENTO DE RECURSO CONTRA DECISÃO QUE CAUSA GRAVAME À PARTE PRINCÍPIO CONSTITUCIONAL DO CONTRADITÓRIO E DA AMPLA DEFESA - Avaliação do imóvel situado na Av. Francisco Morato, São Paulo - Decisão agravada que indeferiu o pedido de complementação do laudo e de esclarecimentos do perito, considerando as avaliações particulares apresentadas pela agravante - Inconformismo da parte - Acolhimento Pronunciamento que ostenta cunho decisório, passível de agravo de instrumento, tendo em vista que o próprio perito destacou que o método involutivo é que mais se aproxima ao valor de mercado - Agravante que tem direito aos haveres na dissolução da sociedade OTAPAN EMPRENDIMENTOS, na proporção de suas quotas sociais, levando-se em conta o valor da universalidade do patrimônio, incluindo todos os bens corpóreos e incorpóreos, ativos e passivos, a fim de que o quinhão represente, efetivamente, a participação da agravante na sociedade RECURSO PROVIDO. (TJSP; Agravo de Instrumento 201156966.2020.8.26.0000; Relator (a): Sérgio Shimura; Órgão Julgador: 2a Câmara Reservada de Direito Empresarial; Foro Central Cível - 37a Vara Cível; Data do Julgamento: 16/06/2020; Data de Registro: 02/07/2020).

“APELAÇÃO. AÇÃO CAUTELAR DE PRODUÇÃO ANTECIPADA DE PROVAS. Sentença homologatória de prova pericial. Insurgência pela ré. Cabimento. Prova pericial antecipada para identificação de defeitos construtivos em imóvel. Despacho que determinou a realização da perícia e a citação da ré, sem que tenha havido efetivo cumprimento do ato citatório, efetivado após a conclusão da prova e entrega do laudo. Nulidade arguida na contestação, primeira oportunidade em que a ré falou nos autos, sem apreciação, sendo proferida sentença homologatória do laudo. Limitações à defesa e recurso (art. 382, §3으 CPC) que dizem respeito ao direito material, objeto de futura demanda, mas não às condições de admissibilidade e observância a requisitos de realização da própria prova a ser antecipada. Ausência de oportunização à ré à formulação de quesitos, indicação de assistente técnico e efetivo acompanhamento à realização da perícia que resultou em violação ao devido processo legal. Sentença anulada, com determinação de retorno dos autos à origem. RECURSO PROVIDO. (TJSP; Apelação Cível 100187155.2016.8.26.0562; Relator (a): Mariella Ferraz de Arruda Pollice Nogueira; Órgão Julgador: 9a Câmara de Direito Privado; Foro de Santos - 9a Vara Cível; Data do Julgamento: 29/06/2020; Data de Registro: 29/06/2020)
} 
Segundo art. 383 do CPC/2015 (BRASIL, 2015), uma vez concretizada a antecipação de provas, o juiz homologará por sentença a respectiva produção; note-se que o julgador não apreciará a prova e nem se manifestará sobre a ocorrência ou não de determinado fato. A sentença será meramente homologatória (THEODORO JÚNIOR, 2015, p. 919).

Bem por isso é que não se verifica coisa julgada material no âmbito da ação autônoma de produção de provas, pois não há declaração de direitos; significa dizer que nem existiria objeto para incidência de uma imutabilidade do comando sentencial. Contudo, é preciso considerar que as partes não podem repetir de forma injustificada a mesma atividade de instrução (WAMBIER et al., 2015b, p. 1042).

Quanto às verbas de sucumbência, entende-se que a responsabilidade pelo custo do processo depende da reação do demandado. Se não houver resistência do réu, as custas e despesas processuais serão arcadas pelo autor; se o réu formular pedido de produção de outro meio de prova ou de apuração de novos fatos relacionados àqueles que 0 autor pretende comprovar, as despesas deverão ser rateadas na medida do interesse de cada parte; havendo resistência do réu, o vencido é que arcará com as despesas e com o pagamento dos honorários de sucumbência. (THEODORO JUNIOR, 2015, p. 919).

Outrossim, quando o art. 383 do CPC/2015 (BRASIL, 2015) dispõe que os autos ficarão em cartório por um mês para a extração de cópias e certidão para os interessados, este dispositivo perdeu o sentido com o advento do processo eletrônico.

É chegada hora de atrelar esse regime jurídico aos casos exemplificados no início do artigo, a fim de checar a utilidade da produção antecipada de provas às hipóteses fáticas surgidas em razão da pandemia de Covid-19.

Tentou-se demonstrar que os reflexos da paralisação de certas atividades atingiram os segmentos da economia de modo diversificado; mesmo para os integrantes de um mesmo segmento as vicissitudes enfrentadas no período da pandemia podem não ser idênticas. Logo, não se poderia afirmar que todas as lojas de confecções sofreram as mesmas consequências da paralisação do comércio; também não se poderia cogitar de que todos os locatários de imóveis comerciais experimentaram os mesmos reflexos econômicos advindos dos períodos de quarentena.
Conforme já se afirmou anteriormente, a incidência de institutos como a frustração do objeto contratual, a onerosidade excessiva e o caso fortuito ou força maior passa, necessariamente, pela verificação concreta de fatos atrelados à realidade circundante de cada relação jurídica, analisada nas suas específicas vicissitudes.

Isso pode ser confirmado mediante 0 estudo de casos que envolvam a onerosidade excessiva, porquanto o art. 478, do Código Civil (BRASIL, 2002), dispõe que nos contratos de execução continuada ou diferida, se a prestação de uma das partes se tornar excessivamente onerosa, com extrema vantagem para a outra, em virtude de acontecimentos extraordinários e imprevisíveis, poderá o devedor pedir a resolução do contrato.

As circunstâncias capazes de tornar uma prestação excessivamente onerosa configuram, inequivocamente, situação de fato. A mesma conclusão aplica-se ao requisito da extrema vantagem e da ocorrência de acontecimentos extraordinários, os quais só podem ser aferidos diante do caso concreto.

Daí que tanto o desequilíbrio superveniente quanto os seus efeitos numa determinada relação jurídica configuram situações de fato que precisam ser valoradas mediante incursões probatórias.

Nesses casos, apresenta-se de extrema utilidade a produção antecipada de provas, a fim de que a parte interessada consiga, previamente, discernir sobre a existência de onerosidade excessiva e sua respectiva extensão. Ademais, o aclaramento dessas situações fáticas pode definir a estratégia da parte entre a resolução ou a revisão do contrato, sem se perder de vista que, a depender do conteúdo da prova produzida em contraditório, as partes fiquem mais propensas às soluções autocompositivas.

\section{CONSIDERAÇÕES FINAIS}

A pesquisa empreendida permitiu constatar que o arrefecimento das atividades econômicas, causado pelos sucessivos períodos de quarentena impostos em razão da pandemia de Covid-19, gerou reflexos diversos entre os vários segmentos da economia. Por conseguinte, as relações jurídicas também foram impactadas de modos díspares, inviabilizando-se um tratamento jurídico que fosse linear, aplicável a toda e qualquer situação. 
Diante da transitoriedade do fenômeno pandêmico, muitas situações jurídicas acabaram ganhando predicados emergenciais, apesar de também transitórios.

Os exemplos citados no curso da exposição em cotejo com os institutos processuais apresentados à discussão permitiram verificar uma significativa utilidade para o regime da estabilização da tutela antecipada, quando requerida antecedentemente, isso porque referida técnica processual seria apta a tutelar, de modo adequado e conveniente, situações emergenciais e transitórias.

De outra parte, a singularidade de cada relação jurídica e as respectivas vicissitudes originadas pela pandemia estão fortemente atreladas a fatos, tudo a ensejar a necessidade de produção de provas a respeito desses mesmos fatos. Daí a estratégia de se conhecer previamente esses fatos, mediante produção de provas em contraditório perante o juiz e a parte adversa.

Nesse contexto, avulta a importância da produção antecipada de provas, seja para incentivar a adoção de métodos autocompositivos, seja para balizar o modo como a parte interessada vai formular eventual demanda em juízo. Fala-se em eventual demanda porque, a depender dos elementos de prova coletados, a parte pode convencer-se de que nem deve ajuizar demanda alguma.

\section{REFERÊNCIAS}

ALVIM, Eduardo Arruda; GRANADO, Daniel Willian; FERREIRA, Eduardo Aranha. Direito processual civil. 6. ed. São Paulo: Saraiva, 2019.

BRASIL. Presidência da República. Lei no 10.406, de 10 de janeiro de 2002. Institui o Código Civil. Diário Oficial da União: seção 1, Brasília, DF, ano 139, n. 8, p. 1-74, 11 jan. 2002.

BRASIL. Presidência da República. Lei no 13.105, de 16 de março de 2015. Código de Processo Civil. Brasília: Secretaria Geral, 2015. Disponível em:

http://www.planalto.gov.br/ccivil_03/_ato20152018/2015/lei/l13105.htm. Acesso em: 28 jun. 2020.

BRASIL. Câmara dos Deputados. Projeto de Lei no 1397/2020, de 01 de abril de 2020. Institui medidas de caráter emergencial mediante alterações, de caráter transitório, de dispositivos da Lei no 11.101, de 9 de fevereiro de 2005; que somente terão vigência até 31 de dezembro de 2020, ou enquanto estiver vigente o Decreto Legislativo no 6, de 20 de março de 2020 (Reconhecimento do estado de calamidade pública em razão da pandemia causada pelo covid-19); e dá outras providências. Brasília, 2020. Disponível em:

https://www.camara.leg.br/proposicoesWeb/fich adetramitacao idProposicao $=2242664$. Acesso em: 27 ago. 2020.

CAPPELLETTI, Mauro; GARTH, Bryant. Acesso à justiça. Trad. Ellen Gracie Northfleet. Porto Alegre: Sérgio Antônio Fabris Editor, 2002.

CARVALHO FILHO, Milton Carlos de. Da tutela de urgência. In: SANTOS, Silas Silva; CUNHA, Fernando Antonio Maia da; CARVALHO FILHO, Milton Paulo de; RIGOLIN, Antonio (coord.). Comentários ao Código de Processo Civil: perspectivas da magistratura. São Paulo: Revista dos Tribunais, 2018. p. 354-382.

CNJ. Conselho Nacional de Justiça. Justiça em Números. Brasília, 2020. Disponível em: https://www.cnj.jus.br/wpcontent/uploads/2020/08/WEB-V3Justi\%C3\%A7a-em-N\%C3\%BAmeros-2020atualizado-em-25-08-2020.pdf. Acesso em: 27 ago. 2020.

CONSELHO NACIONAL DE JUSTIÇA. Justiça em Números. Brasília, 2020.Disponível em: https://www.cnj.jus.br/wpcontent/uploads/conteudo/arquivo/2019/08/just ica_em_numeros20190919.pdf. Acesso em: 27 ago. 2020.

DIDIER JUNIOR, Fredie; BRAGA, Paula Sarno; OLIVEIRA, Rafael Alexandria de. Curso de Direito Processual Civil: teoria da prova, direito probatório, decisão, precedente, coisa julgada e tutela provisória. 10. ed. Salvador: Juspodivm, 2015. v. 2.

DINAMARCO, Candido de. Instituições de direito processual civil. 7. ed. São Paulo: Malheiros, 2017. v. 2.

DINAMARCO, Cândido Rangel. Nova era do processo civil. São Paulo: Malheiros, 2007. 
HAN, Byung-Chul. Sociedade do cansaço. Trad. Enio Paulo Giachini. 2. ed. Petrópolis/RJ: Vozes, 2017.

IURA, Alexandre Miura. Das provas. In: SANTOS, Silas Silva; CUNHA, Fernando Antonio Maia da; CARVALHO FILHO, Milton Paulo de; RIGOLIN, Antonio (coord.). Comentários ao Código de Processo Civil: perspectivas da magistratura. São Paulo: Revista dos Tribunais, 2018. p. 431-440.

JUSTIÇA FEDERAL. Conselho da Justiça Federal. CEJ divulga enunciados da I Jornada de Direito Processual Civil. 2017. Disponível em: https://www.cjf.jus.br/cjf/noticias/2017/setembr o/cej-divulga-enunciados-da-i-jornada-de-direitoprocessual-civil/. Acesso em: 27 jun. 2020.

MARINONI, Luiz Guilherme. Tutela de urgência e tutela da evidência. São Paulo: Revista dos Tribunais, 2017.

MARTINS-COSTA, Judith. Comentários ao novo Código Civil. Rio de Janeiro: Forense, 2003. v. v, t. II.

MEDINA, José Miguel Garcia. Novo Código de Processo Civil Comentado. 4. ed. São Paulo: Revista dos Tribunais, 2016.

MITIDIERO, Daniel. Antecipação da tutela- da tutela cautelar à técnica antecipatória. 3. ed. São Paulo: Revista dos Tribunais, 2017.

NEVES, Daniel Amorim Assumpção. Tutela provisória: manual de direito processual civil. 11. ed. Salvador: Editora JusPodivm, 2019.

SUPERIOR TRIBUNAL DE JUSTIÇA. Informativo no 420. 3ㅇ Turma, Resp no 801.600-CE, Rel. Min. Sidnei Beneti, j. 15.12.2009. Disponível em: www.stj.jus.br > informativos > RTF > Inf0420. Acesso em: 27 ago.2020.

\section{SUPERIOR TRIBUNAL DE JUSTIÇA. Recurso}

Especial n. 1.797.365 / RS. Primeira Turma. Rel. Min. Sérgio Kukina, Rel. para acórdão Min. Regina Helena Costa, recurso especial provido, v.m., j. 3/10/2019, DJe 22/10/2019. Rio Grande do Sul, 2019.Disponível em: https://stj.jusbrasil.com.br/jurisprudencia/85979 3923/recurso-especial-resp-1797365-rs-20190040848-7/inteiro-teor-859793953?ref=serp. Acesso em: 27 ago.2020.
SUPERIOR TRIBUNAL DE JUSTIÇA. Recurso Especial n. 737. 047/SC. Terceira Turma, Rel. Min. Nancy Andrighi, j. 16.02.2006, DJ 13.03.2006, p.321. Disponível em: https://www.jusbrasil.com.br/diarios/152663218 /djdf-07-07-2017-pg-170?ref=topic_feed. Acesso em 27 ago. 2020.

SUPERIOR TRIBUNAL DE JUSTIÇA. Recurso especial no 1.803.251 - SC (2018/0235823-3), Rel. Min. Marco Aurélio Bellizze, julgado em 22.10.2019, DJe de 8.11.2019. Brasília, 2019. Disponível em: https://www.migalhas.com.br/arquivos/2019/11 /CE1EF87751EC2A_acaocpc.pdf. Acesso em: 27 ago. 2020.

TALAMINI, Eduardo. Tutela de urgência no projeto de novo Código de Processo Civil: a estabilização da medida urgente e a "monitorização" do processo civil brasileiro. Revista de processo, São Paulo, n. 209, v. 37, jul., p.13-34, 2012.

TALAMINI, Eduardo. Produção antecipada de prova no Código de Processo Civil de 2015.

Revista de Processo, São Paulo, n. 260, v. 41, p. 75 -101, 2016.

THEODORO JÚNIOR, Humberto; ANDRADE, Érico. A autonomização e a estabilização da tutela de urgência no projeto de CPC. Revista de processo, São Paulo, v. 206, p. 13-59, abr., 2012.

THEODORO JÚNIOR, Humberto. Curso de direito processual civil: teoria geral do direito processual civil, processo de conhecimento e procedimento comum. 56. ed. Rio de Janeiro: Forense, 2015. v. 1.

TRIBUNAL DE JUSTIÇA DE SÃO PAULO. Agravo de instrumento: 2011569-66.2020.8.26.0000; Relator (a): Sérgio Shimura; Órgão Julgador: 2a Câmara Reservada de Direito Empresarial; Foro Central Cível - 37ạ Vara Cível; Data do Julgamento: 16/06/2020; Data de Registro: 02/07/2020. São Paulo, 2020. Disponível em: https://tjsp.jusbrasil.com.br/jurisprudencia/892911356/ag ravo-de-instrumento-ai-20115696620208260000sp-2011569-6620208260000/inteiro-teor892911386?ref=juris-tabs. Acesso em: 27 ago. 2020. 
TRIBUNAL DE JUSTIÇA DE SÃO PAULO. Apelação

cível: 1001871-55.2016.8.26.0562; Relator (a):

Mariella Ferraz de Arruda Pollice Nogueira; Órgão Julgador: 9a Câmara de Direito Privado; Foro de Santos - 9a Vara Cível; Data do Julgamento: 29/06/2020; Data de Registro: 29/06/2020. São Paulo, 2020. Disponível em: https://tj-

sp.jusbrasil.com.br/jurisprudencia/868722717/ap elacao-civel-ac-10018715520168260562-sp1001871-5520168260562. Acesso em: 27 ago. 2020.

WAMBIER, Teresa Arruda Alvim; CONCEIÇÃO, Maria Lúcia Lins; RIBEIRO, Leonardo Ferres da Silva; MELO, Rogerio Licastro Torres de.

Primeiros comentários ao Novo Código de Processo Civil. São Paulo: Revista dos Tribunais, 2015a.

WAMBIER, Teresa Arruda Alvim; DIDIER JUNIOR, Fredie; TALAMINI, Eduardo; DANTAS (coord.). Breves comentários ao Novo Código de Processo Civil. São Paulo: Editora Revista dos Tribunais, 2015b.

YARSHELL, Flávio Luiz. Antecipação de prova sem o requisito da urgência e direito autônomo à prova. São Paulo: Malheiros, 2009.

YARSHELL, Flávio Luiz. Da Produção Antecipada de Prova. In: WAMBIER, Teresa Arruda Alvim; DIDIER JUNIOR, Fredie; TALAMINI, Eduardo; DANTAS (coord.). Breves comentários ao Novo Código de Processo Civil. São Paulo: Editora Revista dos Tribunais, 2015. p. 1026-1042. 